\title{
Exocrine and Endocrine Pancreatic Cancer pT2 TNM Finding v7
}

National Cancer Institute

\section{Source}

National Cancer Institute. Exocrine and Endocrine Pancreatic Cancer pT2 TNM Finding

v7. NCl Thesaurus. Code C90292.

Exocrine or endocrine pancreatic cancer with tumor limited to the pancreas, measuring more than $2 \mathrm{~cm}$ in greatest dimension. (from AJCC 7th Ed.) 